\title{
PENGARUH SANKSI PERPAJAKAN DAN KESADARAN WAJIB PAJAK TERHADAP KEPATUHAN WAJIB PAJAK ORANG PRIBADI DI MANADO
}

\author{
Elfin Siamena1 $^{1}$, Harijanto Sabijono², Jessy D.L Warongan ${ }^{3}$ \\ ${ }^{1,2,3}$ Fakultas Ekonomi dan Bisnis, Jurusan Akuntansi. Universitas Sam Ratulangi, Jl. Kampus Bahu Manado, \\ 95115, Indonesia \\ E-mail : evelinsiamena96@gmail.com
}

\begin{abstract}
The number of taxpayers from year to year increases. But the increase in the number of taxpayers is not offset by taxpayer compliance in paying taxes. The compliance issue becomes an obstacle in maximizing tax revenues. This study aims to analyze the effect of tax sanctions and taxpayer awareness on the compliance of individual taxpayers. The population of this study is determined based on purposive sampling method, the data collected by division of questionnaires in KPP Pratama Manado. The method of research analysis used is multiple linear regression. based on the result of $t$ test, it can be concluded that the tax sanction has positive and significant effect on the taxpayer compliance of the individual, with the value of significance smaller than the significant value $(0.001<0.05)$, the consciousness of the taxpayer positively and significantly influence the compliance personal taxpayer, this is indicated by a value of significance smaller than the significant value $(0.003<0.05)$.

Keywords :Tax sanctions, Taxpayer awareness, Personal taxpayer compliance
\end{abstract}

\section{PENDAHULUAN}

Pembangunan nasional yang secara terus-menerus dan berkesinambungan selama ini, bertujuan untuk meningkatkan kesejahteraan rakyat baik materiil dan spiritual. Untuk mewujudkan tujuan tersebut diperlukan anggaran pembangunan yang cukup besar. Dalam rangka peningkatan kesejahteraan masyarakat secara menyeluruh danuntuk kepentingan pembangunan secara nasional, maka dibutuhkan sumber pembiayaan dan pajak merupakan sumber pembiayaan utama negara, salah satu sumber dana pemerintah adalah penerimaan dari sektor pajak.

Penyelenggarakan pemerintah membutuhkan dana yang relatif besar, dana yang diperlukan tersebut semakin meningkat seiring dengan peningkatan kebutuhan pembangunan itu sendiri. Dalam upaya mengurangi ketergantungan sumber eksternal, pemerintah Indonesia secara terus menerus berusaha meningkatkan sumber pembiayaan pembangunan internal, salah satu sumber pembiayaan pembangunan internal tersebut adalah pajak. Pajak merupakan penerimaan negara terbesar yang dipergunakan untuk membiayai penyelenggaraan pemerintah, pelayanan umum dan pembangunan nasional (Utami, Andi, Soerono, 2012).

Dalam hal peningkatan penerimaan pajak bergantung salah satunya kepada tingkat kepatuhan para wajib pajak. Wajib pajak patuh bukan berarti wajib pajak yang membayar pajak dalam nominal besar dan tertib melaporkan pajaknya melalui SPT, melainkan wajib pajak yang mengerti, memahami dan mematuhi hak dan kewajibannya dalam bidang perpajakan (Khasanah, 2014). Tinggi rendahnya wajib pajak dalam mematuhi kewajiban perpajakannya dipengaruhi oleh beberapa faktor, salah satunya adalah kesadaran wajib pajak. Pemahaman tentang pajak serta kesungguhan wajib pajak untuk melaporkan dan membayar kewajiban perpajakannya dapat mencerminkan tingkat kesadaran wajib pajak, meningkatkan pengetahuan masyarakat tentang perpajakan melalui pendidikanakan membawa dampak positif terhadap kesadaran wajib pajak untuk membayar kewajiban perpajakannya (Alifa, 2012). Tingkat kepatuhanwajib pajak dapat dipengaruhi oleh beberapa faktor, diantaranya adalah persepsi wajib pajak tentang sanksi perpajakan dan kesadaran wajib pajak. Agar 
peraturan perpajakan dipatuhi, maka harus ada sanksi perpajakan bagi para pelanggarnya. Pelaksanaan dan pemberian sanksi yang dimaksud adalah dalam bentuk pemberian sanksi administrasi/denda maupun sanksi pidana. Pada hakikatnya, pengenaan sanksi perpajakan diberlakukan untuk menciptakan kepatuhan wajib pajak dalam melaksanakan kewajiban perpajakannya. Itulah sebabnya, penting bagi wajib pajak memahami sanksi-sanksi perpajakan sehingga mengetahui konsekuensi hukum dari apa yang dilakukan ataupun tidak dilakukan. Berdasarkan uraian latar belakang diatas, maka rumusan masalah dalam penelitian ini adalah :

1. Apakah sanksi perpajakan berpengaruh terhadap kepatuhan wajib pajak orang pribadi?

2. Apakah kesadaran wajib pajak berpengaruhterhadap kepatuhan wajib pajak orang pribadi?

Berdasarkan rumusan masalah yang ada, tujuan dilakukannya penelitian ini adalah untuk mengetahui:

1. Untuk mengetahui seberapa besar pengaruh sanksi perpajakan terhadap kepatuhan wajib pajak orang pribadi.

2. Untuk mengetahui seberapa besar pengaruh kesadaran wajib pajak terhadap kepatuhan wajib pajak orang pribadi.

\section{TINJAUAN PUSTAKA}

\subsection{Konsep Akuntansi}

Akuntansi adalah seni pencatatan, pengklasifikasian, dan pengikthisaran dalam cara yang signifikan dan satuan mata uang, transaksi-transaksi dan kejadian-kejadian yang paling tidak sebagian diantaranya, memiliki sifat keuangan, dan selanjutnya menginterpretasikan hasilnya (American institute of certified Public Accountants dalam Belkaoui, 2015:50). Menurut A Statement of Basic Accounting Theory (ASOBAT) yang diterbitkan oleh American Accounting Association (AAA) pada tahun 1966, akuntansi didefinisikan sebagai proses mengidentifikasi, mengukur, dan menyampaikan informasi ekonomi bagi para penggunanya dalam mempertimbangkan berbagai alternative yang ada dan membuat kesimpulan (dalam Hery, 2013;3).

\subsection{Konsep Akuntansi Pajak}

Akuntansi pajak menurut Agoes dan Estralita (2013:10) Akuntansi pajak adalah menetapkan besarnya pajak terutang berdasarkan laporan keuangan yang disusun oleh perusahaan. Akuntansi pajak merupakan bagian dalam akuntansi yang timbul dari unsur spesialisasi yang menurut keahlian dalam bidang tertentu. Akuntansi pajak tercipta karena adanya suatu prinsip dasar yang diatur dalam Undang-Undang perpajakan dan pembentukannya terpengaruh oleh fungsi perpajakan dalam mengimplementasikan sebagai kebijakan pemerintah.

\subsubsection{Fungsi Pajak}

Menurut Mardiasmo (2016:4), ada 2 (dua) fungsi pajak yaitu:

1. Fungsi Anggaran (Budgetair)

Fungsi yang paling utama dari pajak yaitu suatu fungsi dimana pajak digunakan sebagai alat atau sumber dalam meningkatkan pendapatan atau dana secara optimal ke kas negara, di negara Indonesia sendiri, banyak berbagai jenis pajak yang hal itu sudah diatur dalam konstitusi

2. Fungsi Mengatur (Regulair)

Disebut juga sebagai fungsi mengatur adalah salah satu fungsi pajak yang digunakan oleh pemerintah sebagai alat atau instrument guna mencapai tujuan yang diinginkan, atau tujuan lain yang berhubungan dengan kehidupan masyarakat banyak. Fungsi ini merupakan fungsi tambahan dikarenakan hal ini sebagai pelegkap dari 
fungsi pajak yang lain. Untuk mencapai tujuan terntetu, maka fungsi yang kedua ini sengaja diterapkan, untuk mengatur sehingga tercapai tujuan yang diinginkan.

\subsubsection{Syarat Pemungutan Pajak}

Beberapa syarat pemungutan pajak yang harus dipenuhi berdasarkan Sumarsan (2015:7) yaitu :

1. Pemungutan pajak harus adil

Seperti halnya produk hukum pajak pun mempunyai tujuan untukmenciptakan keadilan dalam hal pemungutan pajak. Adil dalam perundang-undangan maupun adil dalam pelaksanaannya.

2. Pemungutan pajak tidak mengganggu perekonomian

Pemungutan pajak harus diusahakan sedemikian rupa agar tidak mengganggukondisi perekonomian, baik kegiatan produksi, perdagangan, maupun jasa.

3. Pemungutan pajak harus efisien

Biaya-biaya yang dikeluarkan dalam rangka pemungutan pajak harusdiperhitungkan. Jangan sampai pajak yang diterima lebih rendah daripadabiaya pengurusan pajak tersebut. Oleh karena itu, sistem pemungutan pajakharus sederhana dan mudah untuk dilaksanakan.

4. Sistem pemungutan pajak harus sederhana

Sistem yang sederhana akan memudahkan wajib pajak dalam menghitung beban pajak yang harus dibiayai sehingga akan memberikan dampak positif bagi wajib pajak untuk meningkatkan kesadaran dalam pembayaran pajak. Sebaliknya jika sistem pemungutan pajak rumit, orang akan semakinenggan membayar pajak.

\subsubsection{Asas-Asas Pemungutan Pajak}

1. Asas tempat tinggal (domisili)

Asas domisili menyatakan bahwasuatu negara memiliki hak untuk mengenakan pajak kepada semua penghasilan para wajib pajak yang tinggal di wilayah negara tersebut, baik itu penghasilan yang berasal dari dalam negeri, maupun dari luar negeri. Setiap wajib pajak yang tinggal atau berdomisili di wilayah negara Indonesia, dikenakan pajak pada seluruh penghasilannya yang diperoleh dari Indonesia maupun dari luar (Ratnawati \& Hermawati, 2015:7)

2. Asas Sumber

Asas sumber menyatakan bahwa negara berhak mengenakan pajak atas penghasilan yang bersumber di wilayahnya tanpa memperhatikan tempat tinggal wajib pajak (Mardiasmo, 2016:9)

3. Asas Kebangsaan

Dalam asas kebangsaan, yang menjadi landasan penganaan pajak adalah status kewarganegaraan dari orang atau badan yang memperoleh penghasilan. Dalam asas ini, tidak akan diperhatikan sumber penghasilan tersebut (Sumarsan, 2015:11).

\subsubsection{Sistem Pemungutan Pajak}

Menurut Mardiasmo (2016:9) yaitu :

a. Official Assessment System

Official Assessment System adalah suatu sistem pemungutan yang memberi wewenang kepada pemerintah (fiskus) untuk menentukan besarnya pajak yang terutang oleh wajib pajak. Ciri-cirinya: wewenang untuk menentukan besarnya pajak terutang ada pada fiskus, wajib pajak bersifat pasif dan utang pajak timbul setelah dikeluarkan surat ketetapan pajak oleh fiskus.

b. Self Assessment System

Self Assessment System adalah suatu sistem pemungutan pajak yang memberi wewenang kepada wajib pajak untuk menentukan sendiri besarnya pajak yang terutang. Ciricirinya: wewenang untuk menentukan besarnya pajak terutang ada pada wajib pajak sendiri, 
wajib pajak aktif mulai dari menghitung, menyetor dan melaporkan sendiri paja yang terutang, dan fiskus tidak ikut campur dan hanya mengawasi.

c. With holding System

With holding System adalah suatu sistem pemungutan pajak yang memberi wewenang kepada pihak ketiga (bukan fiskus dan bukan wajib pajak yang bersangkutan) untuk memotong atau memungut pajak yang terutang oleh wajib pajak. Ciri-cirinya: wewenang memotong atau memungut pajak yang terutang ada pada pihak ketiga, yaitu pihak selain fiskus dan wajib pajak.

\subsubsection{Tarif Pajak}

1. Tarif Pajak

Tarif pajak adalah tarif berupa angka yang tetap, berapapun dasar pengenaan pajaknya (Ratnawati \& Hermawati, 2015:12).

2. TarifProposional

Tarif proposional adalah tarif yang berupa presentase tertentu yang sifatnya tetap terhadap berapapun dasar pengenaan pajaknya. Sehingga berapapun dasar pengenaan pajaknya, besarnya hutang pajak akan sebanding dengan dasar pengenaan pajak (Ratnawati \& Hermawati, 2015:12).

3. Tarif Progresif

Tarif progresif adalah tarif yang berupa presentase tertentu yang semakin meningkat seiring dengan meningkatnya dasar pengenaan pajak (Ratnawati \& Hermawati, 2015:12).

4. Tarif Degresif

Presentase tarif yang digunakan semakin kecil bila jumlah yang dikenai pajak semakin besar (Mardiasmo, 2016:13).

\subsubsection{Pengelompokan Jenis Pajak}

Menurut Sari Diana (2013:43) :

1. Menurut Sifatnya

2. Menurut Pembebannya

3. Menurut Kewenangannya

\subsection{Sanksi Perpajakan}

Sanksi perpajakan merupakan jaminan bahwa ketentuan perundang-undangan perpajakan (norma perpajakan) akan dituruti, ditaati dan dipatuhi. Atau dengan kata lain sanksi perpajakan merupakan alat pencegah agar wajib pajak tidak melanggar norma perpajakan (Mardiasmo, 2016:62).

\subsubsection{Jenis-Jenis Sanksi Perpajakan}

Mardiasmo (2016:62) menyatakan sanksi perpajakan merupakan jaminan bahwa ketentuan peraturan perundang-undangan perpajakan (normaperpajakan) akan dituruti, ditaati, dipatuhi atau bisa dengan kata lain sanksi perpajakan merupakan alat pencegah (preventif) agar wajib pajak tidak melanggar norma perpajakan.

\subsubsection{Sanksi Administrasi}

1. Sanksi Administrasi Berupa Denda

2. Sanksi Administrasi Berupa Bunga

3. Sanksi Administrasi Berupa Kenaikan

\subsubsection{Sanksi Pidana}

1. Denda Pidana

2. Pidana Kurungan

3. Pidana Penjara

\subsection{Kesadaran Wajib Pajak}

Kesadaran wajib pajak artinya wajib pajak mau dengan sendirinya melakukan kewajiban perpajakannya seperti mendaftarkan diri, menghitung, membayar dan melaporkan jumlah pajak terutangnya (Suand, 2011). 


\subsubsection{Hak-Hak Wajib Pajak}

Dalam Sari Diana (2013:170) hak-hak wajib pajak yang diatur dalam Undang-Undang perpajakan adalah sebagai berikut:

1. Hak untuk mendapatkan pembinaaan dan pengarahan dari fiskus

2. Hak untuk membetulkan Surat Pemberitahuan (SPT)

3. Hak untuk memperpanjang waktu penyampaian SPT

4. Hak untuk menunda atau mengangsur pembayaran pajak

5. Hak memperoleh kembali kelebihan pembayaran pajak

6. Hak mengajukan keberatan dan banding

7. Hak kerahasiaan bagi wajib pajak

8. Hak untuk pengurangan Pajak Bumi dan Bangunan

9. Hak untuk pembebasan pajak

\subsubsection{Kewajiban Wajib Pajak}

KewajibanWajib Pajak dalam Sari Diana (2013:173) yang diatur dalamUndangUndang perpajakan adalah sebagai berikut:

1. Kewajiban untuk mendaftarkan diri

2. Kewajiban mengisi dan menyampaikan Surat Pemberitahuan

3. Kewajiban membayar atau menyetor pajak

4. Kewajiban membuat pembukuan atau pencatatan

5. Kewajiban menaati pemeriksaan pajak

6. Kewajiban melakukan pemotongan atau pemungutan pajak

7. Kewajiban membuat faktur pajak

8. Dalam hal terjadi pemeriksaan pajak

\subsection{Kepatuhan Wajib Pajak Orang Pribadi}

Kepatuhan wajib pajak adalah ketaatan wajib pajak dalam melaksanakan kewajiban perpajakannya sesuai dengan peraturan yang berlaku. Umumnya kepatuhan wajib pajak diukur dariketaatannya dalam membayar dan melaporkan pajaknya, apakah telah dilakukandengan benar sesuai dengan peraturan yang berlaku (Hidayatulloh, 2013).

\subsubsection{Jenis Kepatuhan Wajib Pajak}

Menurut Siti Kurnia Rahayu (2010) sebagaimana dikutip dalam penelitian Kusuma (2016) menyatakan bahwa kepatuhan wajib pajak dapatdibedakan menjadi 2 (dua), yaitu: Kepatuhan Formal dan Kepatuhan Materiil.

\subsection{Tinjauan Penelitian}

1. Hilman Akbar Hidayatulloh (2013) dalam penelitian yang berjudul Pengaruh Kualitas Pelayanan Pajak Dan Pengetahuan Pajak Terhadap Kepatuhan Wajib Pajak (Survey Pada KPP Pratama Bandung Cicadas). Tujuan dari penelitian ini adalah Untuk menganalisis pengaruh kualitas pelayanan pajak dan pengetahuan pajak pada kepatuhan wajib pajak di KPP Pratama Bandung Cicadas. Hasil dari penelitian ini menunjukan Kualitas pelayanan dan pengetahuan pajak secara bersama-sama berpengaruh signifikan terhadap Kepatuhan Wajib Pajak.

2. Lusiana Jayanti Sara (2014) dalam penelitian yang berjudul Pengaruh Pengetahuan Pajak dan Sistem Administrasi Perpajakan Modern Terhadap Kepatuhan Wajib Pajak. Tujuan dari penelitian ini adalah Untuk menentukan pengaruh dari pengetahuan pajak dan sistem administrasi perpajakan modern terhadap kepatuhan wajib pajak di KPP Pratama Bandung Karees. Hasil dari penelitian ini menunjukan Pengetahuan pajak dan sistem administrasi perpajakan modern berpengaruh positifsecara signifikan terhadap kepatuhan wajib pajak di KPP Pratama Bandung. 


\subsection{Kerangka Penelitian}

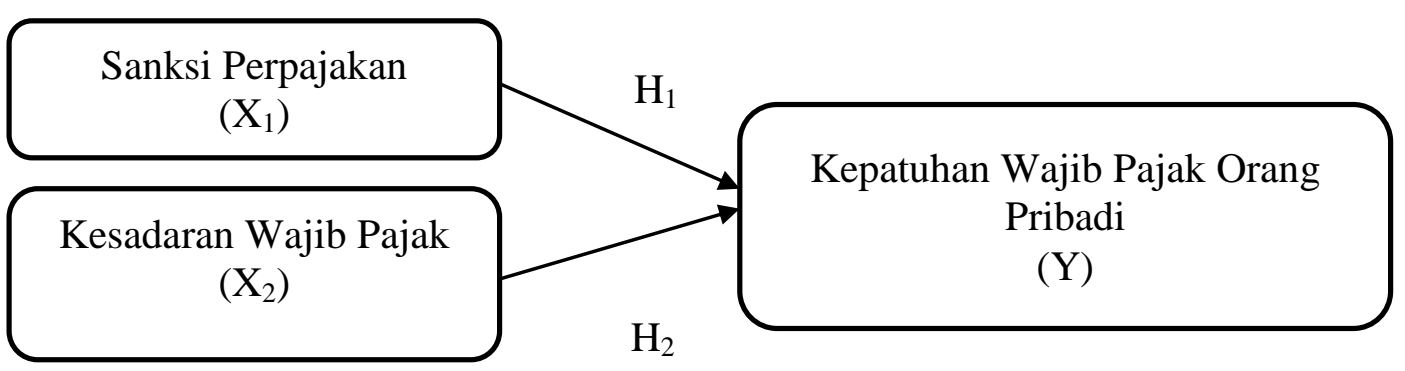

\subsection{Hubungan Antara Variabel}

\subsubsection{Sanksi Perpajakan Terhadap Kepatuhan Wajib Pajak Orang Pribadi}

Sanksi adalah suatu tindakan berupa hukuman yang diberikan kepada orang yang melanggar peraturan (Arum, 2012). Sanksi perpajakan dikenakankepada wajib pajak yang tidak patuh dalam memenuhi perpajakannya (Rohmawati dan Rasmini, 2012). Sanksi pajak memiliki peran penting guna memberikan pelajaran bagipelanggar pajak agar tidak meremehkan peraturan perpajakan dan patuh dalam membayarpajak. Pengenaan sanksi pajak kepada wajib pajak dapat menyebabkan terpenuhinyakewajiban perpajakan oleh wajib pajak sehingga dapat meningkatkan kepatuhan wajib pajakitu sendiri (Widowati, 2014).

\subsubsection{Kesadaran Wajib Pajak Terhadap Kepatuhan Wajib Pajak Orang Pribadi}

Kesadaran wajib pajak adalah sebuah itikad baik seseorang untuk memenuhi kewajiban perpajakannya secara tulus ikhlas tanpa adanya imbalan (Susilawati, 2013). Kesadaran wajib pajak seringkali menjadi kendala dalam masalah pengumpulan pajak dari masyarakat. Kesadaran wajib pajak adalah suatu kondisi dimanawajib pajak mengetahui,memahami dan melaksanakanketentuan perpajakan dengan benar dan sukarela.Semakin tinggi tingkat kesadaran wajib pajak maka pamahamandan pelaksanaan kewajiban perpajakan semakin baik sehingga dapat meningkatkan kepatuhan (Muliari dan Setiawan, 2011).

\subsection{Hipotesis}

Hipotesis merupakan jawaban sementara atas suatu rumusan masalah yang masih harus dilakukan kebenarannya melalui pengujian-pengujian secara empiris.Berdasarkan kerangka penelitian diatas dan penelitian yang dilakukan oleh beberapa peneliti terdahulu maka dapat disusun sebuah hipotesis sebagai berikut:

1. $\mathrm{H}_{1}$ : Sanksi Perpajakan berpengaruh terhadap Kepatuhan Wajib Pajak Orang Pribadi

2. $\mathrm{H}_{2}$ : Kesadaran Wajib Pajak berpengaruh terhadap Kepatuhan Wajib Pajak Orang Pribadi.

3. $\mathrm{H}_{3}$ : Sanksi Perpajakan dan Kesadaran Wajib Pajak berpengaruh terhadap Kepatuhan Wajib Pajak Orang Pribadi

\section{METODE PENELITIAN}

\subsection{Jenis Penelitian}

Menurut Sugiyono (2012:29) penelitian deskriptif adalah metode yang berfungsi untuk mendeskripsikan atau memberi gambaran terhadap objek yang diteliti melalui data atau sampel yang telah terkumpul sebagaimana adanya, tanpa melakukan analisis dan membuat kesimpulan yang berlaku umum. Jenis penelitianyang digunakan adalah jenis penelitian deskriptif dengan menggunakan data kuantitatif yang bertujuan untuk menguji keandalan waktu teori yang kemudian akan menghasilkan kesimpulan-kesimpulan. 


\subsection{Tempat dan Waktu Penelitian}

Penelitian ini dilaksanakan pada KPP Pratama Manado J1. Gunung Klabat, Tanjung Batu. Dengan waktu penelitian dimulai pada bulan Mei 2017 sampai dengan selesai.

\subsection{Prosedur Penelitian}

Adapun langkah-langkah yang dilakukan dalam pelaksanaan penelitian pada KPP Pratama Manado sebagai berikut :

1. Mengidentifikasi permasalahan dan menentukan objek penelitian yang sesuai dengan permasalahan.

2. Mengajukan surat permohonan penelitian untuk penyusunan skripsi kepada pimpinan KPP Pratama Manado

3. Mengumpulkan data dan informasi mengenai pengaruh sanksi perpajakan dan kesadaran wajib pajaka terhadap kepatuhan wajib pajak orang pribadi di KPP Pratama Manado.

4. Melakukan analisis data dan informasi yang di peroleh dari KPP Pratama Manado

5. Menentukan kesimpulan dan saran yang diperlukan berdasarkan penelitian

\subsection{Populasi dan Sampel}

\subsubsection{Populasi}

Menurut Sugiyono (2016:119) Populasi adalah wilayah generalisasiyang terdiri atasobyek/subyek yang mempunyai kualitas dan karateristik tertentu yang ditetapkan oleh peneliti untuk dipelajari dan kemudian ditarik kesimpulannya.

Populasi dalam penelitian ini adalah wajib pajak orang pribadi pada KPP Pratama Manado.

\subsubsection{Sampel}

Menurut Sugiyono $(2016 ; 120)$ Sampel adalah bagian dari jumlah dan karakteristik yang dimiliki oleh populasi tersebut. Pengambilan sampel dilakukan dengan dengan teknik purposive sampling. Metodeini merupakan teknik penentuan sampel dengan pertimbangan tertentu (Sugiyono 2016:126).Teknik ini merupakan salah satu teknik Nonprobability Sampling dimana teknik pengambilan sampel yang tidak memberi peluang/kesempatan sama bagi setiap unsur atau anggota populasi untuk dipilih menjadi sampel (Sugiyono 2016:125).Sampel dalam penelitian ini adalah wajib pajak orang pribadi.Jumlah sampel yang diambil dalam penelitian ini yaitu sebanyak 50 wajib pajak orang pribadi.

\subsection{Metode Pengumpulan Data}

\subsubsection{Jenis Data}

Dalam penelitian ini tentunya diperlukan data yang berhubungan dengan permasalahan yang dihadapi. "Data adalah deskripsi dasar dari benda, peristiwa, aktivitas, dan transaksi yang direkam, dikelompokkan, dan disimpan tetapi belum terorganisir untuk menyampaikan arti tertentu". Data merupakan keterangan-keterangan yang diperoleh dari suatu penelitian yang dilakukan dan atau melalui referensi untuk dapat digunakan dalam menganalisa permasalahan yang dihadapi danselanjutnya mencari pemecahan atas masalah tersebut atau alternatif yang sesuai.

\subsubsection{Sumber Data}

Menurut Supardi (2013:16) menyatakan bahwa pengumpulan data dapat menggunakan dua sumber yaitu sumber primer dan sumber sekunder sebagai berikut;

1. Sumber primer adalah sumber data yang diperoleh atau dikumpulkan langsung oleh orang yang melakukan penelitian atau yang bersangkutan yang memerlukannya. Data primer disebut juga data asli atau data baru.

2. Sumber sekunder merupakan sumber yang tidak langsung memberikan data kepada pengumpul data. Data yang diperoleh atau dikumpulkan dari sumber-sumber yang telah ada.

Sumber data penelitian yang digunakan dalam penelitian ini adalah data primer 


\subsubsection{Teknik Pengumpulan Data}

Teknik pengumpulan data dalam penelitian ini adalah menggunakan kuesioner dan wawancara.

Bobot dan Kategori skala likert

\begin{tabular}{|c|c|c|}
\hline No & Jenis Jawaban Responden & Bobot \\
\hline 1 & SANGAT SETUJU (SS) & 5 \\
\hline 2 & SETUJU (S) & 4 \\
\hline 3 & NETRAL (N) & 3 \\
\hline 4 & TIDAK SETUJU (TS) & 2 \\
\hline 5 & SANGAT TIDAK SETUJU (STS) & 1 \\
\hline
\end{tabular}

\subsection{Metode Analisis Data}

Dalam penelitian akan dianalisis dengan menggunakan analisis statistik yangmeliputi analisis deskriptif, uji kualitas data, uji asumsi klasik, dan uji hipotesis. Berikut adalah uraian dari setiap analisis statistik tersebut.

\subsubsection{Analisis Deskriptif}

Metode analisis deskriptif adalah statistik yang digunakan untuk menganalisis data dengan cara mendeskripsikan atau menggambarkan data yang telah terkumpul sebagaimana adanya tanpa bermaksud membuat kesimpulan yang berlaku untuk umum atau generalisasi (Sugiyono, 2016:199).

\subsubsection{Uji Kualitas Data}

Uji kualitas data ini dilakukan untuk mengetahui validitas dan konsistensi instrument yang digunakan dalam penelitian.Uji kualitas data berupa uji validitas dan uji reliabilitas.

\subsubsection{Uji Validitas}

Uji validitas digunakan untuk mengukur sah atau valid tidaknya suatukuesioner. Kuesioner dikatakan valid jika pertanyaan pada kuesioner mampu untuk mengungkapkan sesuatu yang akan diukur oleh kuesioner tersebut (Sunyoto 2016:85). Suatu item dikatakan valid jika pernyataan pada kuesioner mampu mengungkapkan sesuatu yang akan diukur oleh kuesioner tersebut. Agar data yang diperoleh bisa relevan/sesuai dengan tujuan uji validitas yang digunakan adalah dengan cara menghitung korelasi antara skor setiap konstruknya. Pengujian ini menggunakanmetode Pearson Corelation dimana peneliti ingin membuktikan keberadaan hubungan antara dua variabel. Jika korelasi skor masing-masing butir pertanyaan dengan konstruknya akan dikatakan valid apabila signifikan pada level 0.05.

\subsubsection{Uji Reliabilitas}

Reliabilitas adalah alat untuk mengukur suatu kuesioner yang merupakan indikator dari variabel atau konstruk.Butir pertanyaan dikatakan reliabel atau handal apabila jawaban seseorang terhadap pertanyaan adalah konsisten (Sunyoto 2016:81). Suatu konstruk atau variabel dikatakan reliabel jika memberikan nilai cronbach alpha $>0,60$. Namun ada yang menggunakan 0,70 atau 0,80 atau 0,90 tergantung tingkat kesulitan data dan peneliti.

\subsubsection{Uji Asumsi Klasik}

Setelah uji kualitas data, selanjutnya akan diuji asumsi klasik untuk mengetahui distribusi data, hubungan antara variabel independen, dan konsistensi varian penganggu. Menurut Ghozali (2013) dalam membuat uji asumsi klasik harus menggunakan data yang akan digunakan dalam uji regresi. Uji asumsi klasik yang digunakan terdiridari Uji Normalitas, Uji Multikoloneritas, dan Uji Heteroskedastisitas.

\subsubsection{Analisis Regresi Linear Berganda}

Analisis regresi akan menggunakan regresi linear berganda untuk meguji pengaruh sanksi perpajakan dan kesadaran wajib pajak terhadap kepatuhan wajib pajak orang pribadi.Analisis regresi linear berganda adalah jumlah variabel independenlebih dari satu 
(ganda), sedangkan hubungannya tetap linear (Taniredja \& Mustafidah, 2014:92).Persamaan analisis regresi linear berganda yang digunakan adalah sebagai berikut:

$$
\mathrm{Y}=\alpha+\beta 1 X 1+\beta 2 \times 2+\mathrm{e}
$$

\subsubsection{Pengujian Hipotesis Penelitian}

Uji Signifikansi Parameter Individual (Uji t)

a. Ho1 : $\beta=0$,Sanksi perpajakan (X1) secara persial tidak berpengaruh siginifikan pada variabel kepatuhan wajib pajak orang pribadi $(\mathrm{Y})$

b. Ha2 : $\beta \neq 0$, Sanksi perpajakan (X1) secara persialberpengaruh siginifikan pada variabel kepatuhan wajib pajak orang pribadi (Y)

c. Ho1 : $\beta=0$, Kesadaran wajib pajak (X2) secara persial tidak berpengaruh siginifikan pada variabel kepatuhan wajib pajak orang pribadi (Y)

d. Ha2 : $\beta=0$, Kesadaran wajib pajak (X2) secara persial berpengaruh siginifikan pada variabel kepatuhan wajib pajak orang pribadi (Y)

\subsection{Defenisi dan Pengukuran Variabel}

\subsubsection{Kalasifikasi Variabel}

1.Variabel bebas (Independen variable) adalah variabel yang mempengaruhiatau yang menjadi sebab perubahannya atau timbulnya variabel dependen (Sugiyono, 2016:64).Variabel independen dalam penelitian ini adalah sanksi perpajakan dan kesadaran wajib pajak.

2.Variabel terikat (Dependent) adalah variabel yang dipengaruhi atauyang menjadi akibat, karena adanya variabel bebas (Sugiyono, 2016:64).Variabel dependen dalam penelitian ini adalah kepatuhan wajib pajak orang pribadi.

\subsubsection{Defenisi Operasional Variabel}

1. Variabel Bebas (Independent)

a. Sanksi Pajak

b. Kesadaran Wajib Pajak

2. Variabel Terkait (Dependent)

a. Kepatuhan dalam mendaftarkan diri ke kantor pajak

b. Kepatuhan dalam melaporkan SPT tepat pada waktunya

c. Kepatuhan dalam menghitung dan membayar pajak dengan benar

d. Kepatuhan dalam membayar tunggakan pajak.

\section{HASIL PENELITIAN DAN PEMBAHASAN}

\subsection{Hasil Penelitian}

\subsubsection{Pengaruh Sanksi Perpajakan Terhadap Kepatuhan Wajib Pajak Orang Pribadi}

Berdasarkan hasil uji t menunjukkan bahwa nilai thitung lebih besar dari nilai $t_{\text {hitung }}$ $(3,453>2,011) t_{\text {tabel }}$ dan nilai signifikansi yang lebih kecil daripada nilai signifikan $5 \%$ $(0,001<0,05)$. Hal ini menunjukkan bahwa sanksi perpajakan secara parsial mempunyai pengaruh terhadap kepatuhan wajib pajak orang pribadi.Hasil penelitian ini menunjukkan bahwa terdapat hubungan yang signifikan dan positif antara sanksi perpajakan dengan kepatuhan wajib pajak orang pribadi. Hal ini berarti semakin tinggi sanksi perpajakan, maka kepatuhan wajib pajakakan tercapai dan menjadi semakin meningkat.

\subsubsection{Pengaruh Kesadaran Wajib Pajak Terhadap Kepatuhan Wajib Pajak Oran Pribadi}

Hasil perhitungan regresi menunjukkan nilai koefisien regresi positif dari variabel kesadaran wajib pajak dengan kepatuhan wajib pajak orang pribadi.Uji t menunjukkan bahwa nilai $t_{\text {hitung }}$ lebih besar dari pada nilai $t_{\text {tabel }}(3,188>2,011)$ dan nilai signifikansi yang lebih kecil daripada nilai signifikan $5 \%(0,003<0,005)$. Hal ini menunjukkan bahwa kesadaran 
wajib pajak secara parsial mempunyai pengaruh terhadap kepatuhan wajib pajak orang pribadi. Dalam hal ini berarti semakin tinggi kesadaran wajib pajak, maka kepatuhan wajib pajak tentu akan semakin meningkat pula.

\subsubsection{Pengaruh Sanksi Perpajakan dan Kesadaran Wajib Pajak Terhadap Kepatuhan Wajib Pajak Orang Pribadi}

Berdasarkan hasil uji $\mathrm{f}$ menunjukkan bahwa nilai $\mathrm{f}$ hitung lebih besar dari nilai $\mathrm{f}$ tabel $(14,540>3,20)$ dan nilai signifikan yang lebih kecil dari pada nilai signifikansi $5 \%(0,000<$ 0,005). Hal ini menunjukkann bahwa sanksi perpajakan dan kesadaran wajib pajak berpengaruh secara bersama-sama secara simultan terhadap kepatuhan wajib pajak orang pribadi.

\section{PENUTUP}

\subsection{Kesimpulan}

Berdasarkan hasil pembahasan diatas, maka dapat ditarik kesimpulan sebagai berikut:

1. Sanksi Perpajakan berpengaruh secara positif dan signifikan terhadap kepatuhan wajib orang pribadi. Dimana semakin tegas sanksi perpajakan maka kepatuhan wajib pajak akan semakin meningkat. Hal ini ditunjukkan dengan nilai $t_{\text {hitung }}$ lebih besar daripada nilai $t_{\text {tabel }}(3,453>2,011)$ dan nilai signifikansi yang lebih kecil daripada nilai signifikan $5 \%(0,001<0,05)$.

2. Kesadaran Wajib Pajak berpengaruh secara positif dan signifikan terhadap kepatuhan wajib orang pribadi. Dimana semakin tinggi tingkat kesadaran perpajakan wajib pajak maka semakin meningkat tingkat kepatuhan wajib pajak. Hal ini ditunjukkan nilai $t_{\text {hitung }}$ lebih besar dari pada nilai $t_{\text {tabel }}(3,188>2,011)$ dan nilai signifikansi yang lebih kecil dari pada nilai signifikan $5 \%(0,003<0,005)$.

\subsection{Saran}

Berdasaran kesimpulan diatas, maka penulis dapat memberikan saran sebagai berikut;

1. Petugas pajak perlu memperhatikan kualitas pelayananyang diberikannya kepada wajib pajak, sehingga akan meningkatkan penerimaan pajak.

2. Petugas pajak harus lebih aktif memberikan informasi dan pemungutan pajak terhadap wajib pajak sehingga wajib pajak tau kapan harus membayar dan terhindar dari sanksi.

3. Penelitian selanjutnya dapat menggunakan variabel lainnya sehingga untuk selanjutnya dapat ditemukan variabel baru yang akan mempengaruhi kepatuhan wajib pajak.

\section{DAFTAR PUSTAKA}

Alifa Nur Rohmawati dan Ni Ketut Rasmini. 2012. Pengaruh Kesadaran, Penyuluhan, Pelayanan, dan Sanksi Perpajakan Pada Kepatuhan Wajib Pajak Orang Pribadi. EJurnal Akuntansi Universitas Unadaya. Vol. 1, No. 2 Desember 2012.

Belkout dan Ahmed Riahi.Accounting Theory. buku 1,5 ed Jakarta, Salemba 22012

Ghozali, Iman. 2013. Aplikasi Analisis Multivariat dengan Program IBM SPSS.21. Edisi 7. Semarang, Penerbit Universitas Dipenegoro.

Harjanti Puspa Arum, Zulaikha. 2012. Pengaruh Kesadaran Wajib Pajak, Pelayanan Fiskus, dan Sanksi Pajak terhadap Kepatuhan Wajib Pajak Orang Pribadi yang Melakukan Kegiatan Usaha dan Pekerjaan Bebas (Studi di Wilayah KPP Pratama Cilacap). Jurusan Akuntansi Fakultas Ekonomi dan Bisnis Universitas Diponegoro, Semarang.

Hery. 2013. Auditing (Pemeriksaan Akuntansi I) Cetakan Pertama, Jakarta: CAPS (Center of Academic Publishing Service).

Khasanah, Septiyani Nur. 2014. Pengaruh Pengetahuan Perpajakan, Modernisasi Sistem Administrasi Perpajakan, dan Kesadaran Wajib Pajak Terhadap Kepatuhan Wajib Pajak Pada Kantor Wilayah Direktorat Jendral Pajak Daerah Istimewa Yoygakarta. Skripsi. Yogyakarta: Fakultas Ekonomi - Universitas Negeri Yogyakarta. 
Mardiasmo. 2016. Perpajakan. Edisi Revisi. Yogyakarta, Andi.

Muliarni dan Setiawan. 2011. Pengaruh Persepsi Tentang Sanksi Perpajakan Dan Kesadaran Wajib Pajak Pada Kepatuhan Pelaporan Wajib Pajak Orang Pribadi di Kantor Pelayanan Pajak Pratama Denpasar Timur.

Ratnawati, J. Dan R. Indah Hernawati. 2015. Dasar-Dasar Perpajakan. Deepublish, Yogyakarta

Sari, Diana. 2013. Konsep Dasar Perpajakan. Bandung, PT Refika Aditama.

Siti Kurnia Rahayu. 2010. Perpajakan Indonesia, Yogyakarta : Graha Ilmu

Suandy, Erly. 2011. Hukum Pajak, Edisi 5, Jakarta: Salemba Empat.

Sumarsan, Thomas. 2015. Perpajakan Indonesia. Edisi4: Indeks, Jakarta

Sugiyono. 2016. Metode Penelitian Kombinasi. Bandung, Alfabeta.

Sunyoto, Danang. 2016. Metodologi Penelitian Akuntansi. Bandung. PT Refika Aditama

Susilawati, Evi Ketut. 2013. Pengaruh Kesadaran Wajib Pajak, Pengetahuan Pajak, Sanksi Perpajakan Dan Akuntabilitas Pelayanan Publik Pada Kepatuhan Wajib Pajak Kendaraan Bermotor. Jurnal Fakultas Ekonomi Universitas Udayana 2 ISSN: 23028556. Hal. 345-357.

Supardi, 2013. Aplikasi Statistika Dalam Penelitian. Jakarta: Penerbit Smart

Tukiran Taniredja \& Hidayati Mustafidah. 2014. Penelitian Kuantitatif. Bandung, Alfabet

Widowati, Rizky. 2014. Kepatuhan Wajib Pajak Melalui Sosialisaai Perpajakan, Sanksi Perpajakan, Pengetahuan Pajak dan Pelayanan Fiskus. Universitas Dian Nuswantoro Semarang - Falkutas Ekonomi \& Bisnis

Utami, Sri Rizki, Andi dan Ayu Noorida Soerono. 2012. Pengaruh Faktor-Faktor Eksternal Terhadap Tingkat Kepatuhan Wajib Pajak Di Lingkungan Kantor Pelayanan Pajak Pratama Serang. Universitas Sultan Ageng Tirtayasa. 